\title{
INFLUENCE OF ELECTROLYTE ON THE ZIRCONIUM ELECTROLYSIS PROCESS FOR NUCLEAR POWER ENGINEERING
}

\author{
A.P. Mukhachev, V.G. Nefedov*, O.A. Kharytonova** \\ Institute of Geotechnical Mechanics, Dnipro, Ukraine; \\ *State University of Chemical Technology, Dnipro, Ukraine; \\ **Dniprovskyi State Technical University, Kamyanske, Ukraine \\ E-mail: eah@ukr.net
}

The work presents the results of a study of the cathode and anode processes of zirconium electrolysis from molten electrolytes $\mathrm{K}_{2} \mathrm{ZrF}_{6}-\mathrm{KCl}-\mathrm{KF}-\mathrm{KI}$ and $\mathrm{ZrF}_{4}-\mathrm{KCl}-\mathrm{KF}$. It is shown that the introduction of iodine compounds into the electrolyte prevents the discharge of potassium chloride, reduces the release of chlorine on the anode, the consumption of electricity, reagents and increases the current efficiency and process productivity. The replacement of $\mathrm{K}_{2} \mathrm{ZrF}_{6}$ obtained by fractional crystallization on $\mathrm{ZrF}_{4}$ salt with a hafnium content of less than $0.01 \%$ obtained after the extraction process reduces the consumption of $\mathrm{Zr}$ salt, eliminates the accumulation of KF in the electrolyte, reduces the consumption of hydrofluoric acid and potassium carbonate, and increases the concentration of zirconium in the electrolyte, increases current efficiency and improves powder quality to ASTM hafnium requirements.

\section{INTRODUCTION}

The production of zirconium with a content of metallic impurities of less than $0.1 \%$ and hafnium of less than $0.01 \%$ for nuclear power is the most important task of the nuclear industry [1,2]. WCPR-1000 nuclear fuel, as a structural material, uses an alloy of zirconium with niobium, which has high neutron-physical properties and corrosion resistance [1]. These properties depend on the purity of the metal, which is determined by the process for producing. An industrial method of producing zirconium powder by open electrolysis at $750 \ldots 800{ }^{\circ} \mathrm{C}$ from $\mathrm{K}_{2} \mathrm{ZrF}_{6}-\mathrm{KCl}-\mathrm{KF}$ electrolyte was developed in 1964. $\mathrm{K}_{2} \mathrm{ZrF}_{6}$ was first obtained by alloying zircon with potassium silicofluoride, followed by fractional crystallization of $\mathrm{K}_{2} \mathrm{ZrF}_{6}$ to separate $\mathrm{K}_{2} \mathrm{HfF}_{6}$ [3]. In accordance with TS (Technical Specifications) 19 95.259-77, the content of hafnium in zirconium was established at the level of $0.035 \%$ of the mass. This Hf content exceeded the ASTM standard by 5 times, which reduced the degree of uranium burning at nuclear power plants. Gaseous impurities from zirconium powder (oxygen and nitrogen) were removed during iodide refining, which hindered the development of zirconium production.

$\mathrm{K}_{2} \mathrm{ZrF}_{6}$ production, with $\mathrm{Hf}$ content of less than $0.01 \%$ [4], requires 18 stages of fractional crystallization.

The electrochemical method for producing plastic zirconium in the Russian Federation is competitive, since the initial $\mathrm{K}_{2} \mathrm{ZrF}_{6}$ salt has a low cost, and the electric current is cheap and environmentally friendly reducing agent. The electrolysis process in sealed electrolyzers of 10 and $20 \mathrm{kA}$ allows us to obtain a metal of nuclear purity of $99.7 \ldots 99.9 \%$. Critical impurities - oxygen, nitrogen and carbon are at the level of $0.05,0.004$, and $0.02 \%$, respectively. The disadvantages of the production process of zirconium from the electrolyte $\mathrm{K}_{2} \mathrm{ZrF}_{6}-\mathrm{KCl}-\mathrm{KF}$ are the following:

- high consumption of potassium chloride with the formation of chlorine, which is not used;

- the formation of aggressive anode gas, consisting of a mixture of chlorine and atmospheres dangerous for ozone, F11-14 freons;
- the formation and accumulation of potassium fluoride $(\mathrm{KF})$, which requires periodic drain of the electrolyte with deterioration of the powder quality. This operation results in energy consumption increase, consumption of salts $\mathrm{Zr}$ and $\mathrm{KCl}$, which increases the cost of the process;

- the fluorine content increase in the electrolyte leads in the appearance of anode effect, as a result of which the voltage at the electrodes increases, energy consumption rises, and the destruction process of graphite anodes is accelerated;

- the formation of an oxidized powder in a volume of $20 \%$ requires purification from gas impurities by the expensive method of iodide refining.

The aim of this work was to show the possibility of improving the electrolysis process by selecting the composition of the electrolyte in order to reduce the consumption of electricity and reagents, the cost of zirconium.

\section{TECHNIQUE OF INDUSTRIAL}

$\mathrm{K}_{2} \mathrm{ZrF}_{6}-\mathrm{KCl}-\mathrm{KF}$ electrolytes with the addition of $\mathrm{KI}$ and $\mathrm{ZrF}_{4}-\mathrm{KCl}-\mathrm{KF}$ were studied for zirconium electrolysis. Zirconium salts, $\mathrm{K}_{2} \mathrm{ZrF}_{6}$ and $\mathrm{ZrF}_{4}$, were obtained in the process of extraction separation of $\mathrm{Zr}$ and Hf. The feedstock for the preparation of zirconium salts was zircon containing $65 \%$ of the sum of $\mathrm{Zr}$ and $\mathrm{Hf}(2 \% \mathrm{Hf})$ and $35 \% \mathrm{SiO}_{2}$. It was fused with sodium carbonate at a temperature of $1150{ }^{\circ} \mathrm{C}$ in a ratio of $1: 3.5$. Zirconium was converted to sodium zirconate, which was well soluble in nitric acid. Zirconium purification from hafnium to the content of the latter less than $0.005 \%$, as well as from metal impurities to a level of $10^{-2} \ldots 10^{-3} \%$, carried out during extraction using tributyl phosphate. To obtain $\mathrm{K}_{2} \mathrm{ZrF}_{6}$, a zirconium reextract was used, which was processed with potassium carbonate and $40 \%$ hydrofluoric acid. Zirconium fluoride was precipitated with hydrofluoric acid from concentrated zirconium solution. Zirconium and $\mathrm{KCl}$ fluoride salts were dried to a moisture content of $0.05 \%$ and entered a sealed electrolyzer. The quality of the zirconium salts for the electrolysis process is shown in Table 1. 
The purity of the raw materials used in the electrolysis

\begin{tabular}{|l|c|c|c|c|c|c|c|}
\hline \multirow{2}{*}{ Product name } & \multicolumn{7}{|c|}{ Content of impurities, \% mass } \\
\cline { 2 - 9 } & $\mathrm{Hf}$ & $\mathrm{Si}$ & $\mathrm{Ti}$ & $\mathrm{Cr}$ & $\mathrm{Al}$ & $\mathrm{Ni}$ & $\mathrm{Fe}$ \\
\hline $\mathrm{K}_{2} \mathrm{ZrF}_{6}$ after fractional crystallization & 0.05 & 0.06 & 0.005 & 0.01 & 0.003 & 0.05 & 0.03 \\
\hline $\mathrm{ZrF}_{4}$ after extraction < (TS) & 0.01 & 0.02 & 0.004 & 0.01 & 0.003 & 0.005 & 0.03 \\
\hline $\mathrm{K}_{2} \mathrm{ZrF}_{6}$ after extraction $<$ (TS) & 0.01 & 0.02 & 0.004 & 0.01 & 0.003 & 0.005 & 0.03 \\
\hline
\end{tabular}

The $\mathrm{K}_{2} \mathrm{ZrF}_{6}-\mathrm{KCl}-\mathrm{KF}-\mathrm{KI}$ electrolyte (16-21-63\%, respectively) was tested in a $10 \mathrm{kA}$ electrolyzer, and the $\mathrm{ZrF}_{4}-\mathrm{KF}$ electrolyte - in a $20 \mathrm{kA}$ electrolyzer. The iodine content in the electrolyte was regulated in the range from $0.03 \ldots 0.5 \%$. The electrolyzer was powered by $\mathrm{KCl}$ and $\mathrm{KI}$ autonomously with the salts $\mathrm{K}_{2} \mathrm{ZrF}_{6}$, $\mathrm{ZrF}_{4}$.

In the $\mathrm{ZrF}_{4}-\mathrm{KCl}-\mathrm{KF}$ electrolyte, the zirconium content was $5.5 \ldots 6 \%$, chlorine $-10 \%$, fluorine $-23 \%$. The electrolysis process took place with the following parameters [5]:

- voltage, $\mathrm{U}, \mathrm{V}-25.0 \pm 2.0$

- cathode current density $\mathrm{i}_{\mathrm{K}}, \mathrm{A} / \mathrm{cm}^{2}-3.0 \pm 0.2$

- anode current density $\mathrm{i}_{\mathrm{A}}, \mathrm{A} / \mathrm{cm}^{2}-0.2 \ldots 0.3$

- temperature $\mathrm{T},{ }^{\circ} \mathrm{C}-750 \pm 50{ }^{\circ}$

During the experiment, the degree of extraction of the powder, the chemical composition of the powder, electrolyte and anode gases, the consumption of $\mathrm{Zr}$ salt of electricity and reagents were determined. For comparison, the cathode product was processed using $\mathrm{K}_{2} \mathrm{CO}_{3}$ and $\left(\mathrm{NH}_{4}\right)_{2} \mathrm{CO}_{3}$, and the anode gas was sanitized with $20 \%$ solutions of sodium hydroxide and milk of lime.

\section{RESULT AND DISCUSSION 2.1. CATHODE PROCESSES IN ELECTROLYTES 1, 2, AND 3}

The mechanism of cathode processes for the $\mathrm{K}_{2} \mathrm{ZrF}_{6}-\mathrm{KCl}-\mathrm{KF}$ electrolyte was described in [6]. It was shown that the current efficiency of the zirconium extraction reaction is low, about 55\%, which is connected with the occurrence of parallel reactions at the cathode, one of which is the reduction of potassium. Its presence in zirconium powder was detected by washing the cathode product with a solution of potassium carbonate. The cathode processes in the $\mathrm{K}_{2} \mathrm{ZrF}_{6}-\mathrm{KCl}-\mathrm{KF}-\mathrm{KI}$ electrolyte can also be described by the reactions:

$$
\begin{gathered}
\left(\mathrm{ZrF}_{6}\right)^{2-}+4 e \rightarrow \mathrm{Zr}+6 \mathrm{~F}^{-}, \\
K^{+}+e \rightarrow K^{0} .
\end{gathered}
$$

The cathode processes in the $\mathrm{ZrF}_{4}-\mathrm{KCl}-\mathrm{KF}$ electrolyte practically do not differ from the $\mathrm{K}_{2} \mathrm{ZrF}_{6}$ $\mathrm{KCl}-\mathrm{KF}$ electrolyte. Replacing $\mathrm{K}_{2} \mathrm{ZrF}_{6}$ with $\mathrm{ZrF}_{4}$ reduced salt consumption and energy consumption for melting KF molecules.

The current efficiency of zirconium in this electrolyte increased to $85 \ldots 90 \%$, but the release of potassium metal remained. The cathode process when replacing $\mathrm{K}_{2} \mathrm{ZrF}_{6}$ with $\mathrm{ZrF}_{4}$ is described by the equations:

$$
\begin{gathered}
Z_{r F_{4}}+4 e \rightarrow Z r^{0}+4 F^{-}, \\
K^{+}+e \rightarrow K
\end{gathered}
$$

\subsection{ANODE PROCESSES IN ELECTROLYTE 1 $\left(\mathrm{K}_{2} \mathrm{ZrF}_{6}-\mathrm{KCl}-\mathrm{KF}\right)$}

The following reactions can occur at the anode:

- discharge of fluorine ion. The enthalpy of formation, for example, of freon-11 is $-42 \mathrm{kcal} / \mathrm{mol}$. The potential of fluorine release as a result of depolarization during interaction with the anode graphite decreases from 2.93 to $0.9 \mathrm{~V}$.

$$
\mathrm{C}+\mathrm{F}^{-}-e \rightarrow C F \text {. }
$$

The resulting carbon fluoride is adsorbed on the surface of the anode.

- discharge of a chlorine ion. Chlorine ion can be discharged to molecular chlorine by reaction

$$
2 \mathrm{Cl}^{-}-2 e \rightarrow \mathrm{Cl}_{2} \text {. }
$$

The discharge potential of a chlorine-ion at an electrolysis temperature is $1.2 \mathrm{~V}$. The chlorine discharge potential is achieved due to the large overvoltage of fluoride release. The appearance of freon shifts the discharge potential of the chlorine ion to $+0.78 \mathrm{~V}$ and the following reaction may occur:

$$
\mathrm{CF}+\mathrm{Cl}^{-}-e \rightarrow \mathrm{CFCl} \text {. }
$$

This substance is thermodynamically unstable and disproportionate with the formation of freons-11, 12, 13 according to the following reactions:

$$
\begin{gathered}
3 \mathrm{CFCl} \rightarrow \mathrm{CCl}_{3} \mathrm{~F}+2 \mathrm{C}+\mathrm{F}_{2}, \\
2 \mathrm{CFCl} \rightarrow \mathrm{CCl}_{2} \mathrm{~F}_{2}+\mathrm{C}, \\
3 \mathrm{CFCl} \rightarrow \mathrm{CClF}_{3}+\mathrm{Cl}_{2} .
\end{gathered}
$$

Freons formed in the anode process are thermodynamically stable.

The process of carbon tetrafluoride formation accelerates with an excess of fluorine-ion in the electrolyte:

$$
\mathrm{CF}+3 \mathrm{~F}^{-}-3 e \rightarrow \mathrm{CF}_{4}
$$

that results in the appearance of the anode effect, which reduces the current efficiency. This process can proceed only by the electrochemical mechanism. The concentration of carbon tetrafluoride in the anode gas in the closed mode of the electrolysis process does not exceed $20 \%$. The total content of freons-11, 12, 13 also does not exceed $20 \%$. The chlorine content in the anode gas is approximately 60 . 


\subsection{ANODE PROCESSES IN ELECTROLYTE 2 $\left(\mathrm{K}_{2} \mathrm{ZrF}_{6}-\mathrm{KCl}-\mathrm{KF}-\mathrm{KI}\right)$}

The analysis of the operation of the electrolyzer with an electrolyte of the indicated composition showed that the $\mathrm{KCl}$ discharge in this electrolyte was significantly reduced. KF formation decreased. Specific energy consumption has decreased. Periodic drain of a part of the electrolyte with accumulated KF disappeared. This reduced the oxidation of zirconium powder and improved the quality of the resulting product. The current efficiency increased from 55 to $65 \%$.

When KI is added to the electrolyte, the discharge of chlorine at the anode decreases, from 0.8 to $0.05 \mathrm{~kg}$ per $1 \mathrm{~kg}$ of powder per day, therefore, the chlorine released is sufficient only for the formation of freon-13 by the reaction:

$$
3 \mathrm{CF}+\mathrm{Cl}^{-}-e \rightarrow \mathrm{CClF}_{3}+2 \mathrm{C} .
$$

The analysis of the anode gas showed that it contains $\mathrm{CClF}_{3}-35 \%, \mathrm{CF}_{4}-60 \%$, the rest is impurities $\mathrm{N}_{2}, \mathrm{O}_{2}$, $\mathrm{CO}$, and $\mathrm{CO}_{2}$.

The release of fluorine with a given composition of the electrolyte begins at $E=0.9 \mathrm{~V}$, which allows it to get ahead of the chlorine discharge and react with carbon.

The formation of a thermodynamically strong $\mathrm{CF}_{4}$ compound at the anode according to reaction (11) maintains a high rate of interaction of graphite with fluorine and accelerates the rate of graphite destruction as a result of the anode effect. The consumption of carbon during the formation of freons-13 and 14 $(12.3 \mathrm{~kg} /$ day $)$ significantly exceeds its consumption (7 kg/day) with the joint formation of chlorine and a mixture of freons-11, 12, 13, 14. The content of freon14 in the anode gas with the introduction of $\mathrm{KI}$ increases with 20 to $60 \%$, and $\mathrm{CClF}_{3}$ from 5 to $35 \%$. The formation of freons 11 and 12 in this case is absent.

It is noteworthy that iodine was not detected in the anode gas, and its content in the electrolyte during the electrolysis remains approximately constant. Two variants of the participation of iodine in the anode process can be suggested.

1. Iodine is adsorbed on the anode, increasing its wettability, but does not enter into an electrochemical reaction. From the point of view of thermodynamics, this option is unlikely, since the potential for the release of iodine from an individual salt melt at a temperature of $700{ }^{\circ} \mathrm{C}$ is $+0.146 \mathrm{~V}$ [4], which is much less than chlorine and fluorine, even taking into account their depolarization.

2. Iodine is oxidized at the anode by the reaction:

$$
2 J^{-}-2 e \rightarrow J_{2},
$$

and then it is restored in the anode layer of the electrolyte, after which it again takes part in the anode process.

\subsection{ANODE PROCESSES IN ELECTROLYTE 3 $\left(\mathrm{ZrF}_{4}-\mathrm{KCl}-\mathrm{KF}\right)$}

Replacing $\mathrm{K}_{2} \mathrm{ZrF}_{6}$ with $\mathrm{ZrF}_{4}$ does not affect the halogen discharge mechanism at the anode. The amount of freon formed is determined by the presence of free chlorine and fluorine on the anode. $0.83 \mathrm{~kg}$ of fluorine is discharged per $1 \mathrm{~kg}$ of zirconium powder, of which only $0.06 \mathrm{~kg}$ of fluorine is released into the gas phase and forms freons, the rest of the fluorine goes to the formation of KF. The discharge of chlorine ion at the anode, as a side process, causes an increased consumption of $\mathrm{KCl}$ and the formation of potassium, which interacts with fluorine. The absence of KF in $\mathrm{ZrF}_{4}$ and the decrease of electrolyte fluoride by $3 \ldots .5 \%$ makes the electrolyte less viscous and more conductive, which significantly reduces energy consumption.

\subsection{PROCESSES IN THE VOLUME OF ELECTROLYTE}

The electrolysis of the molten electrolyte proceeds at significant temperature gradients and density gradients. It is accompanied by intense gas evolution at the anode. This is a condition for the appearance of convective flows of considerable velocity in the electrolyte volume. As a result, metal potassium formed in liquid form at the cathode (potassium melting point $-63.5^{\circ} \mathrm{C}$, electrolysis temperature $\left.-(750 \pm 50){ }^{\circ} \mathrm{C}\right)$ is washed off and transferred to the electrolyte volume and to the anode space. Here, potassium can react with fluorine formed by reaction (8), forming potassium fluoride:

$$
2 K+F_{2} \rightarrow 2 K F \text {. }
$$

This leads to an increase in its concentration in electrolyte No. 1 and the need for periodic discharge of the electrolyte. In addition, potassium can restore iodine in electrolyte No. 2 :

$$
2 \mathrm{~K}+\mathrm{I}_{2} \rightarrow 2 \mathrm{KI}
$$

Therefore, its concentration in the electrolyte remains constant. Iodine is practically absent in the anode gas. A decrease in the concentration of iodine in the electrolyte is possible due to the entrainment of the electrolyte with the cathode product.

\subsection{TOTAL REACTIONS}

Based on the above electrode reactions, the process of $\mathrm{Zr}$ electrolysis from $\mathrm{K}_{2} \mathrm{ZrF}_{6}$ in electrolyte №1 can be described by the equation

$$
7 \mathrm{~K}_{2} \mathrm{ZrF}_{6}+18 \mathrm{KCl}+4 \mathrm{C} \pm 28 e \rightarrow 7 \mathrm{Zr}+32 \mathrm{KF}+6 \mathrm{Cl}_{2}+\mathrm{CClF}_{3}+\mathrm{CCl}_{2} \mathrm{~F}_{2}+\mathrm{CCl}_{3} \mathrm{~F}+\mathrm{CF}_{4} \text {. }
$$

The presence of freons-11, 12, 13, 14 was confirmed by chromatographic analysis.

In electrolyte $\mathrm{N} 2$, chromatographic analysis of the anode gas obtained by electrolysis of $\mathrm{K}_{2} \mathrm{ZrF}_{6}$ with the addition of $\mathrm{KI}$ showed the absence of chlorine and

$$
4 \mathrm{~K}_{2} \mathrm{ZrF}_{6}+2 \mathrm{KCl}+4 \mathrm{C} \pm 16 e \rightarrow 4 \mathrm{Zr}+10 \mathrm{KF}+2 \mathrm{CClF}_{3}+4 \mathrm{CF}_{4} \text {. }
$$

The electrolysis process from electrolyte $\mathrm{N} 3 \mathrm{ZrF}_{4}-\mathrm{KCl}-\mathrm{KF}$ is described by the equation:

$$
5 \mathrm{ZrF}_{4}+10 \mathrm{KCl}+4 \mathrm{C} \pm 20 \mathrm{e} \rightarrow 5 \mathrm{Zr}+10 \mathrm{KF}+2 \mathrm{Cl}_{2}+\mathrm{CClF}_{3}+\mathrm{CCl}_{2} \mathrm{~F}_{2}+\mathrm{CCl}_{3} \mathrm{~F}+\mathrm{CF}_{4} \text {. }
$$




\subsection{ANALYSIS OF THE OPERATION OF ELECTROLYZERS}

Analysis of the operation of the electrolyzer with a current load of $10 \mathrm{kA}$ on electrolyte $\mathrm{N} 2\left(\mathrm{~K}_{2} \mathrm{ZrF}_{6}-\mathrm{KCl}-\right.$ $\mathrm{KF}-\mathrm{KI})$ showed that its productivity increases to $10 \%$, compared with electrolyte $\mathrm{N} 1 . \mathrm{KCl}$ consumption is reduced from 218.0 to $40.0 \mathrm{~kg}$ per day. $\mathrm{KCl}$ discharge decrease in the presence of iodine ions leads to a 1.8fold decrease in the formation of ballast $(\mathrm{KF})$, stabilizes the electrolyte level and the electrolysis process. The current efficiency increases up to $65 \%$, the consumption of electricity and salts decreases, as shown in Table 2.

Table 2

The output of chlorine and freons at the anode and the energy consumption for various electrolyte compositions

\begin{tabular}{|c|l|c|c|c|c|c|}
\hline No & Electrolyte/Composition & $\begin{array}{c}\mathrm{Zr} \text { current } \\
\text { efficiency, } \\
\%\end{array}$ & $\begin{array}{c}\text { Freon output, } \\
\mathrm{kg} / 1 \mathrm{~kg} \text { of } \\
\text { powder }\end{array}$ & $\begin{array}{c}\text { Electricity } \\
(\mathrm{kW} \cdot \mathrm{h}) / \mathrm{kg}\end{array}$ & $\begin{array}{c}\text { Chlorine output } \\
\text { per } 1 \mathrm{~kg} \text { of } \\
\text { powder }\end{array}$ & $\begin{array}{c}\text { Carbon } \\
\text { consumption } \\
\text { per } 1 \mathrm{~kg} \text { of } \\
\text { powder }\end{array}$ \\
\hline 1 & $\mathrm{~K}_{2} \mathrm{ZrF}_{6}-\mathrm{KCl}-\mathrm{KF}$ & 50.0 & 1.00 & 70.0 & 0.60 & 0.074 \\
\hline 2 & $\mathrm{~K}_{2} \mathrm{ZrF}_{6}-\mathrm{KCl}-\mathrm{KF}-\mathrm{KI}$ & 65.0 & 1.0 & 56.0 & 0.032 & 0.10 \\
\hline 3 & $\mathrm{ZrF}_{4}-\mathrm{KCl}-\mathrm{KF}$ & $85 \ldots 90.0$ & 1.0 & 40.0 & 0.35 & 0.06 \\
\hline
\end{tabular}

The concentration of $\mathrm{F}^{-}$in the electrolyte decreases, from 27.0 to $22.0 \%$. The total consumption of the mixture of salts $\mathrm{K}_{2} \mathrm{ZrF}_{6}$ and $\mathrm{KCl}$, when $\mathrm{KI}$ is introduced, decreases from 578 to $340 \mathrm{~kg}$ per day, i.e. 1.7 times. The specific consumption of $\mathrm{NaOH}$ alkali for purification of gas from chlorine, because of the reduction of its output, decreases from 0.7 to $0.01 \mathrm{t}$ per $1 \mathrm{t} \mathrm{Zr}$.

In general, this leads to a reduction in energy consumption from $56(\mathrm{~kW} \cdot \mathrm{h}) / \mathrm{kg}$ of zirconium powder to $40(\mathrm{~kW} \cdot \mathrm{h}) / \mathrm{kg}$ and the cost of $\mathrm{Zr}$.

The formation of freons, F13 and F14 on the anode allows them to be extracted from the anode gas, after it is cooled. The separation process is made possible by a very different evaporation temperature, which is respectively -81.4 and $+28^{\circ} \mathrm{C}$. Freon processing will improve the environmental safety of the process of electrolytic production of zirconium.

The $\mathrm{CF}_{4}$ content in the anode gas is less than $20 \%$, however, as a result of the anode effect it can increase to $30 \%$ or more. This accelerates the destruction of the anode and increases the carbon content in the cathode product.

It is of interest to estimate the rate of destruction of the anode for various electrolyte compositions.
The carbon consumption is determined by the formula:

$$
m=\frac{v M_{C} Q_{Z r}}{M_{Z r F 4}},
$$

where $M_{C}$ is the molecular weight of carbon; $M_{Z r F 4}-$ molecular weight of the $\mathrm{Zr}$ salt; $\mathrm{Q}_{\mathrm{Zr}}$ - daily consumption of salt $\mathrm{Zr}$.

Calculation by formula (19) showed that the highest anode destruction rate is observed in the $\mathrm{K}_{2} \mathrm{ZrF}_{6}-\mathrm{KCl}-$ $\mathrm{KF}$ electrolyte. It is equal to $0.07 \mathrm{~kg}$ of carbon per $1 \mathrm{~kg}$ of powder. The rate of destruction of the anode in the electrolyte $\mathrm{K}_{2} \mathrm{ZrF}_{6}-\mathrm{KCl}-\mathrm{KF}-\mathrm{KI}$ and $\mathrm{ZrF}_{4}-\mathrm{KCl}-\mathrm{KF}$ is 0.10 and $0.01 \mathrm{~kg}$ per $1 \mathrm{~kg}$ of powder. The decrease of destruction rate of the anode is apparently caused by a decrease in the concentration of KF in the electrolyte by $5 . .7 \%$ and an increase in the concentration of $\mathrm{Zr}$ by $20 \%$. The electrolyte composition also affects the discharge of chlorine ions.

The output of chlorine and freons at the anode and the energy consumption for various electrolyte compositions are also shown in Table 2. The consumption of salts in the electrolysis process is shown in Table 3.

Consumption of salts during the electrolysis of various electrolytes

\begin{tabular}{|c|c|c|c|c|c|}
\hline $\begin{array}{c}\text { Electrolyte/ } \\
\text { Composition }\end{array}$ & $\begin{array}{c}\text { Powder } \\
\text { output, } \\
\mathrm{kg} / \text { day }\end{array}$ & $\begin{array}{c}\text { Salt } \\
\text { consumption } \mathrm{Zr}, \\
\mathrm{kg}\end{array}$ & $\begin{array}{c}\mathrm{KCl} \\
\text { consumption } \\
\mathrm{kg} / \text { day }\end{array}$ & $\begin{array}{c}\mathrm{KCl} \\
\text { consumption } \\
\text { per 1 kg of } \mathrm{Zr} \\
\text { salt }\end{array}$ & Notes \\
\hline $1 . \mathrm{K}_{2} \mathrm{ZrF}_{6}-\mathrm{KCl}-\mathrm{KF}$ & 100.0 & 390.0 & 218.0 & 0.60 & $\begin{array}{l}\text { Taking into account } \\
\text { the drain of } \\
\text { electrolyte and } \\
\mathrm{K}_{2} \mathrm{ZrF}_{6} \text { entrainment } \\
\text { with } \mathrm{CP}^{*}\end{array}$ \\
\hline 2. $\mathrm{K}_{2} \mathrm{ZrF}_{6}-\mathrm{KCl}-\mathrm{KF}-\mathrm{KI}$ & 110.0 & $\begin{array}{c}372.0 \\
\mathrm{~K}_{2} \mathrm{ZrF}_{6}\end{array}$ & 80.0 & 0.27 & $\begin{array}{c}\mathrm{K}_{2} \mathrm{ZrF}_{6} \text { entrainment } \\
\mathrm{K}_{2} \mathrm{ZrF}_{6} \text { with } \mathrm{CP}^{*}\end{array}$ \\
\hline $3 . \mathrm{ZrF}_{4}-\mathrm{KCl}-\mathrm{KF}$ & 206.0 & $\begin{array}{c}428.0 \\
\mathrm{ZrF}_{4}\end{array}$ & 120.0 & 0.10 & $\mathrm{ZrF}_{4}$ entrainment \\
with $\mathrm{CP}^{*}$
\end{tabular}

* $\mathrm{CP}$ - cathode product.

Comparative performance indicators of a $20 \mathrm{kA}$ electrolyzer with electrolytes $\mathrm{N} 1$ on $\mathrm{K}_{2} \mathrm{ZrF}_{6}$ and N 3 with $\mathrm{ZrF}_{4}$ are given in Table $\mathrm{N} 4$. 
Comparative performance of the electrolyzer with a current load of $20 \mathrm{kA}$

\begin{tabular}{|l|c|c|}
\hline \multicolumn{1}{|c|}{ Indicators of electrolysis process } & \multicolumn{2}{|c|}{$\mathrm{Zr}$ salts } \\
\cline { 2 - 3 } & $\mathrm{K}_{2} \mathrm{ZrF}_{6}$ & $\mathrm{ZrF}_{4}$ \\
\hline 1. Operation time of electrolyzer in cycle, day & 61.4 & 65.0 \\
\hline 2. Direct current load, kA & 20.1 & 23.0 \\
\hline 3. Voltage, V & 18.0 & 15.0 \\
\hline 4. Specific power consumption, $\mathrm{kWh} / \mathrm{kg}$ & 56.0 & 40.0 \\
\hline 5. Concentration in electrolyte, \% $\mathrm{Zr}$ & $5.0 \pm 0.5$ & $5.5 \pm 0.5$ \\
$\mathrm{KCl}$ & 19.0 & 22.0 \\
$\mathrm{KF}$ & 65.0 & 69.0 \\
\hline 6. Temperature of electrolysis, ${ }^{\circ} \mathrm{C}$ & $760 \ldots 800$ & $760 \ldots 800$ \\
\hline 7. Direct metal output, \% & 69.6 & 90.0 \\
\hline
\end{tabular}

The $\mathrm{Zr}$ content in the $\mathrm{ZrF}_{4}$ salt increases from 32.1 to $54 \%$, which makes it possible to raise the $\mathrm{Zr}$ concentration in the electrolyte to $6.0 \%$ and improve the productivity of the electrolyzer from 180 to $206 \mathrm{~kg}$ of powder per day. During electrolysis, KF is formed much less. This will keep the electrolyte level in the bath constant without draining the electrolyte.

Salt replacement increased the current efficiency to $85 \%$, which allowed us to reduce the specific power consumption from 56.0 to $40 \mathrm{~kW} \cdot \mathrm{h}$ per $1 \mathrm{~kg}$ of powder, Table 5 .

The effect of electrolyte composition on the technological parameters of electrolysis

\begin{tabular}{|l|c|c|c|}
\hline $\begin{array}{c}\text { Electrolyte/ } \\
\text { Composition }\end{array}$ & $\begin{array}{c}\text { Current } \\
\text { efficiency, } \%\end{array}$ & $\begin{array}{c}\text { Freon output, kg/1 kg } \\
\text { of powder }\end{array}$ & Power consumption \\
\hline $1 . \mathrm{K}_{2} \mathrm{ZrF}_{6}-\mathrm{KCl}-\mathrm{KF}$ & 55.0 & 1.00 & 70.0 \\
\hline $2 . \mathrm{K}_{2} \mathrm{ZrF}_{6}-\mathrm{KCl}-\mathrm{KF}-\mathrm{KI}$ & 66.0 & 1.0 & 56.0 \\
\hline $3 . \mathrm{ZrF}_{4}-\mathrm{KCl}-\mathrm{KF}$ & 90.0 & 1.0 & 40.0 \\
\hline
\end{tabular}

The operation time of the electrolysis in a closed mode increases due to the exclusion of the operation of draining the electrolyte up to $90 \%$, which improves the quality of the powder for gas impurities and reduces its cost by reducing the cost of iodide refining.

$\mathrm{Zr}$ salt consumption decreased to $214 \mathrm{~kg} / \mathrm{day}$, and $\mathrm{KCl}$ - to $160 \mathrm{~kg}$ in terms of electrolysis in the electrolyzer $10 \mathrm{kA}$, since the electrolyte was not drained.

The electrolysis on the compositions $\mathrm{N} 2$ and 3 eliminates the drainage of the electrolyte, which improves all technological parameters of the process. The transition to zirconium tetrafluoride increases the productivity of electrolysis process, improves the quality of zirconium, while reducing the consumption of electricity and reagents.

\section{CONCIUSIONS}

1. The use of zirconium fluoride salts obtained after extraction separation of zirconium and hafnium allows us to reduce the hafnium content in zirconium from 0.035 to $\leq 0.005 \%$ of metallic impurities to $0.05 \%$ of the mass and improve the nuclear physical properties of products made of alloys of zirconium with niobium.

2. The introduction of $\mathrm{KI}$ into the $\mathrm{K}_{2} \mathrm{ZrF}_{6}$ electrolyte reduces the consumption of potassium chloride and the formation of $\mathrm{KF}$, which eliminates the drainage of the electrolyte, increases the extraction of zirconium and its current efficiency, reduces the energy consumption, and eliminates the formation of molecular chlorine.
3. The addition of KI to the electrolyte in the range of $0.03 \ldots 0.5 \%$ leads to decrease of the chlorine content in the anode gas and the consumption of reagents for its capture.

4. Replacing potassium fluorozirconate with zirconium fluoride also eliminates drainage of the electrolyte, reduces the consumption of zirconium and potassium chloride salts, and the energy consumption. This increased the current efficiency to $80 \ldots 90 \%$.

5 . The use of new electrolytes increased the service life of graphite anodes from 50 to 75 days.

6 . The termination of the drain of the electrolyte led to operating time increase in closed mode and reduced the output of oxidized powder and the cost of its processing.

\section{REFERENCES}

1. И.Я. Емельянов, В.Г. Аден, В.П. Борщев и др. Оценка экономической эффективности использования в реакторах РБМК циркониевых сплавов с улучшенными нейтронно-физическими характеристиками // VI Отраслевая конференция по гидрометаллургии ичиркония. Днепродзержинск, 1986, с. $16-19$.

2. А.К. Шиков, В.Н. Безумов и др. Разработка процессов получения и исследования свойств первичного электролитического циркония с содержанием гафния $<1000$ ppm слитков и изделий из циркониевых сплавов // XIV Международная конференция по физике радиационных явлений $и$ 
радиационному материаловедению. Алушта, Крым. Харьков, 2000, с. 107.

3. Ядерная энергетика. Обращение с отработанным топливом и радиоактивными отходами / Под ред. И.М. Неклюдова. Киев: «Наукова думка», 2006, 253 с.

4. Основы металлургии. М.: «Металлургия», 1967, т. VI, c. $348-349$.

5. А.Н. Огарев, И.П. Галкин, А.Т. Неделяев и др. Внедрение и промышленное освоение герметичных электролизеров на 20 кА // VI Отраслевая конференция по гидрометаллургии циикония. Днепродзержинск, 1986, с. 156-158.

6. A.P. Mukhachev, V.G. Nefedov, O.A. Kharytonova. Electrode process in electrolysis of zirconium. Production of plastic zircony for nuclear energy // Problems of Atomic Science and Technology. 2019, N 2(120), p. 111-115.

\title{
ВЛИЯНИЕ ЭЛЕКТРОЛИТА НА ПРОЦЕСС ЭЛЕКТРОЛИЗА ЦИРКОНИЯ ДЛЯ ЯДЕРНОЙ ЭНЕРГЕТИКИ
}

\author{
А.П. Мухачев, В.Г. Нефедов, Е.А. Харитонова
}

Изложены результаты исследования катодных и анодных процессов электролиза циркония из расплавленных электролитов $\mathrm{K}_{2} \mathrm{ZrF}_{6}-\mathrm{KCl}-\mathrm{KF}-\mathrm{KI}$ и $\mathrm{ZrF}_{4}-\mathrm{KCl}-\mathrm{KF}$. Показано, что ввод соединений йода в электролит препятствует разряду хлористого калия; сокращает выделение на аноде хлора, расход электроэнергии и реагентов; увеличивает выход по току и производительность процесса. $3 \mathrm{ameна} \mathrm{K}_{2} \mathrm{ZrF}_{6}$, полученного методом дробной кристаллизации, на соль $\mathrm{ZrF}_{4}$ с содержанием гафния менее $0,01 \%$, которая получена после процесса экстракции, снижает расход соли $\mathrm{Zr}$, исключает накопление $\mathrm{KF}$ в электролите, сокращает расход плавиковой кислоты и углекислого калия, повышает концентрацию циркония в электролите, увеличивает выход по току и улучшает качество порошка до требований стандарта ASTM по гафнию.

\section{ВПЛИВ ЕЛЕКТРОЛІТУ НА ПРОЦЕС ЕЛЕКТРОЛІЗУ ЦИРКОНІЮ ДЛЯ ЯДЕРНОЇ ЕНЕРГЕТИКИ}

\section{А.П. Мухачов, В.Г. Нефедов, О.А. Харитонова}

Викладено результати дослідження катодних і анодних процесів електролізу цирконію з розплавлених електролітів $\mathrm{K}_{2} \mathrm{ZrF}_{6}-\mathrm{KCl}-\mathrm{KF}-\mathrm{KI}$ i $\mathrm{ZrF}_{4}-\mathrm{KCl}-\mathrm{KF}$. Показано, що введення сполук йоду в електроліт перешкоджає розряду хлористого калію, скорочує виділення на аноді хлору, витрату електроенергії і реагентів, збільшує вихід по струму і продуктивність процесу. Заміна $\mathrm{K}_{2} \mathrm{ZrF}_{6}$, отриманого методом дробової кристалізації, на сіль $\mathrm{ZrF}_{4}$, 3 вмістом гафнію менше $0,01 \%$, яка отримана після процесу екстракції, знижує витрату солі Zr, виключає накопичення KF в електроліті, скорочує витрату плавикової кислоти і вуглекислого калію, підвищує концентрацію цирконію в електроліті, збільшує вихід по струму і покращує якість порошку до вимоги стандартів ASTM по гафнію. 